\title{
Prevalence of Extended-spectrum $\beta$-lactamases in Escherichia coli Isolated from Chicken, Water and the Poultry Farm Workers
}

\author{
Sana Ilyas', Muhammad Hidayat Rasool ${ }^{1, *}$, Muhammad Javed Arshed², \\ Muhammad Usman Qamar ${ }^{1}$ and Bilal Aslam ${ }^{1}$ \\ ${ }^{1}$ Department of Microbiology, Government College University, Faisalabad, Pakistan \\ ${ }^{2}$ National Veterinary Laboratory, National Agriculture Research Council, Islamabad, \\ Pakistan
}

\begin{abstract}
A B S T RA C T
The Enterobacteria harboring the extended-spectrum- $\beta$-lactamase (ESBL) are a serious threat to public health particularly in developing countries. The study was aimed to investigate the prevalence and genomic characterization of ESBL producing $E$. coli from poultry, environment and poultry farm workers in Islamabad and Rawalpindi Pakistan. A total of 250 poultry samples, 92 poultry environmental samples, and 50 poultry farm worker's urine samples were screened for ESBL producing E. coli using ChromeID ${ }^{\mathrm{TM}}$ ESBL agar. Biochemical confirmation of the isolates was carried out by API 20E. The antimicrobial susceptibility profiling and phenotypic confirmation of ESBL producers were performed as per CLSI 2018 guidelines. The minimum inhibitory concentration of ESBL producing isolates was determined by the broth dilution method. Phenotypically confirmed ESBL producing strains were further subjected to molecular characterization for the presence of ESBL and carbapenemase-producing genes using PCR. Of 392 samples, 219 ESBL positive $E$. coli were recovered and among these 156/213 (73.2\%), 42/63 $(66.6 \%)$ and $21 / 27(77.7 \%)$ were from poultry, environmental water, and urine samples, respectively. The PCR results revealed that $71.2 \%$ of $b l a, 67.5 \%$ bla $a_{\text {and }}$ and $62.2 \%$ bla $a_{\text {TEM }}$ producing isolates were recovered from poultry, $19.1 \% \mathrm{bla}_{\mathrm{CTX- \textrm {M }}}, 21.6 \% \mathrm{bla}_{\mathrm{CTX- \textrm {M } - 1}}, 36.8 \% \mathrm{bla} a_{\mathrm{TEM}}$ from environment and $9.6 \%$ $b l a_{\text {СтХ-м }}, 10.8 \% b l a_{\text {СТХ-М - }} 0.8 \%$ bla $_{\text {TЕм }}$ from urine samples. Moreover, bla $a_{\text {СтХ-м-2 }}(\mathrm{n}=19), b l a_{\text {СТХ-м-8 }}$ group $(\mathrm{n}=19)$ and bla $_{\text {СТХ-M-9 }}$ group $(\mathrm{n}=27)$ were only observed in poultry samples. In addition, carbapenemase

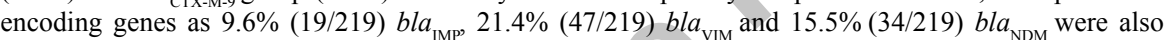
detected. ESBL producing $E$. coli exhibited resistance against cephalosporins, $\beta$-lactamase inhibitors, monobactam, folate-pathway inhibitors, fluoroquinolones, and aminoglycosides. This study investigates the high prevalence of ESBL producing $E$. coli in chicken, farmworkers, and water that is alarming and could lead to serious threats to both livestock and public health.
\end{abstract}

\begin{tabular}{l} 
Article Information \\
\hline Received 28 February 2020 \\
Revised 03 April 2020 \\
Accepted 13 April 2020 \\
Available online 21 October 2020 \\
Authors' Contribution \\
\hline SI conducted research work and wrote \\
the article. MHR and MJA supervised \\
the work. MUQ and BA helped in \\
manuscript write up. \\
Key words \\
ESBL-Escherichia coli, \\
Carbapenemases, Environmental \\
water, Poultry, Poultry farm workers
\end{tabular}

\section{INTRODUCTION}

$\mathrm{E}$ xtended-spectrum- $\beta$-lactamase (ESBL) producing Enterobacteriaceae particularly Escherichia coli are becoming a serious threat to the public health sector globally, mainly in developing countries like Pakistan (Aslam et al., 2018). The use of antimicrobial agents in animals, poultry and agriculture have recognized benefits, but overuse has potentially serious implications for human health such as the development of antimicrobial resistance (AMR). In 2010 , livestock consumed about 63,200 tons of antibiotics, which could increase to 105,600 tons by 2030 globally (Van Boeckel et al., 2015). According to the United Nation, by 2050 , one person will die every three seconds and more than 10 million people die annually with an economic

\footnotetext{
Corresponding author: drmhrasool@gcuf.edu.pk 0030-9923/2021/0001-0001\$9.00/0 Copyright 2021 Zoological Society of Pakistan
}

burden of above $\$ 100$ trillion if AMR is not properly managed now. There are around 700,000 people die each year globally due to drug-resistant infections (Brogan and Mossialos, 2016). Two Pakistani studies also documented that AMR pathogens are responsible for 4/9 children death and $57 \%$ of children died due to the septicemia caused by AMR pathogens (Khan et al., 2016; Khurshid et al., 2017; Qamar et al., 2015).

In Pakistan, there is indiscriminate and extensive use of antibiotics in livestock, particularly in the poultry industry. Moreover, there is the same antibiotic regime (cephalosporins, macrolides, aminoglycosides, and fluoroquinolones) is being used in both animals and humans (Rehman et al., 2017). This overuse/misuse of antibiotics leads to the selection of resistant bacteria among animals and poultry. Hence, these resistant bacteria are transmitted to humans through various routes or may allow susceptible human pathogens to acquire resistance through genetic transfer, which leads to the emergence of new resistant 
strains (Landers et al., 2012). ESBL producing E. coli is frequently involved in various infections such as sepsis, pneumonia, gastroenteritis, and urinary tract infections (Abraham et al., 2012). ESBL producing E. coli showed resistant against a wide range of $\beta$-lactam drugs and $\beta$-lactam inhibitors except for carbapenems which are considered the last resort to treat infections caused by such pathogens (Canton et al., 2012). There are 224 bla $_{\text {СТХ-M, }}$ 228 bla $_{\mathrm{SHV}}$ and 237 bla $_{\mathrm{TEM}}$ ESBL genotypes that have been reported so far (Naas et al., 2017). Recently, a Pakistani study reported the prevalence of ESBL producing $E$. coli $\left(\right.$ bla $_{\text {CTX-M, }}, b l a_{\mathrm{SHV}}, b l a_{\text {OXA-48 }}$ ) from both poultry meat and poultry farm environment (Rahman et al., 2018). Similarly, another study from Pakistan also revealed the presence of carbapenemases and ESBL producing E. coli from poultry (Ahmad et al., 2018). One Health approach has been proposed as the key to study the transmission dynamics of AMR. As per our knowledge, there are limited data available on the "Pakistan One Health issue" so far. Hence, we have planned this study to investigate the presence and spread of ESBL producing E. coli from poultry, environmental water, and poultry workers from twin cities, Pakistan.

\section{MATERIALS AND METHODS}

\section{Ethical consideration}

Before starting the research work, ethical approval was obtained from the Ethical Review Committee, Government College University, Faisalabad, Pakistan.

\section{Collection of samples}

A total of 250 poultry samples (chicken ceca) from live bird market, 92 water samples ( 23 poultry drinking water, 38 poultry wastewaters, 31 community sewage) and 50 urine samples from poultry farm workers (Table II) were collected aseptically during February 2018 to July 2019 from different areas of Islamabad and Rawalpindi, Pakistan. The geographic location of the sample area is given in Figure 1. The chicken ceca samples were kept in the sterile plastic bags and water samples $(50 \mathrm{ml})$ were collected in $100 \mathrm{ml}$ sterilized bottles (Beninati et al., 2015). The poultry workers were given the sterile container and requested to provide a $10-20 \mathrm{ml}$ urine sample for examination. Samples were immediately transported to the bacteriology research laboratory under refrigerated conditions $\left(5^{\circ} \mathrm{C} \pm 3\right)$ for further analysis.

\section{Isolation and ESBL confirmation of Escherichia coli}

For the separation of cecal sacs and interstitial material, sterilized scissors were used to open 1-2 cm incision in the wall of the cecum. For each cecal sample,
$1 \mathrm{~g}$ of cecal content was placed into $9 \mathrm{ml}$ of buffered peptone water and tubes were incubated at $37^{\circ} \mathrm{C}$ for $22 \mathrm{~h}$ aerobically. Further, $10 \mu 1$ of each sample was cultured on MacConkey agar containing cefotaxime $(4 \mathrm{mg} / \mathrm{L})$ (MAC-CEF) and plates were incubated at $37^{\circ} \mathrm{C}$ for $22 \mathrm{~h}$ aerobically. Similarly, $10 \mu \mathrm{l}$ of urine sample was streaked on MacConkey and MAC-CEF agar and plates were incubated for 22 hours at $37^{\circ} \mathrm{C}$. Moreover, $1 \mathrm{ml}$ of poultry water sample was diluted 10 -folds in $9 \mathrm{ml}$ of phosphate buffer saline and $100 \mu 1$ of the sample from each dilution was inoculated on MacConkey and MAC-CEF agar and plates were incubated at $37^{\circ} \mathrm{C}$ for $22 \mathrm{~h}$ aerobically. The presumptive pink-colored $E$. coli colonies were further sub-cultured on ChromeID ${ }^{\mathrm{TM}}$ ESBL agar for the screening of ESBL (BioMérieux, France) and plates were incubated at $37^{\circ} \mathrm{C}$ for $22 \mathrm{~h}$. The preliminary identification was done based on their colonial morphology, culture characteristics and biochemically confirmed by API 20E (BioMérieux, France). Confirmed ESBL-producing E. coli strains were stored in Tryptic Soy Broth (TSB) containing glycerol in duplicate at $-20^{\circ} \mathrm{C}$ and $-80^{\circ} \mathrm{C}$.

Presumptive confirmation of ESBL producing E. coli was determined by a combination disc diffusion method as per CLSI 2018 guidelines. ESBL positive strain Klebsiella pneumoniae ATCC 700603 was used for positive control.

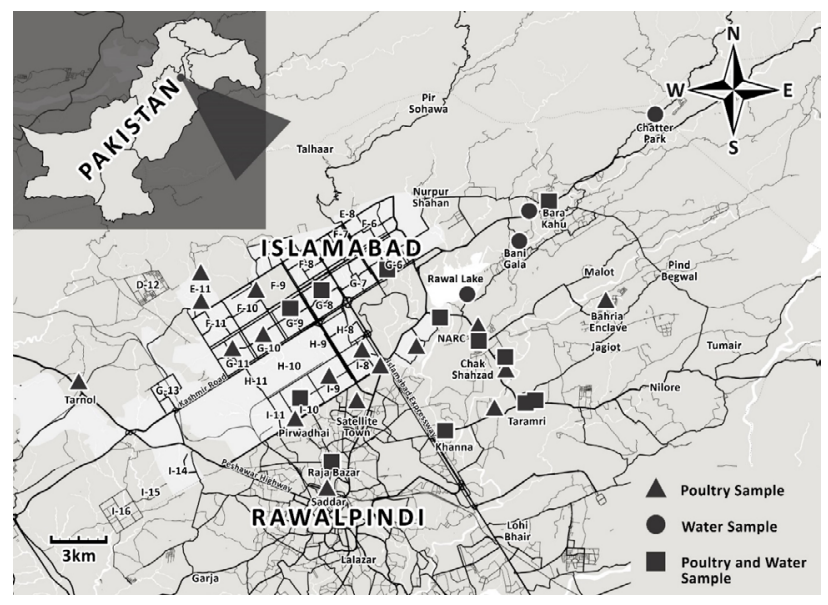

Fig. 1. Poultry and water sampling areas from Islamabad and Rawalpindi, Pakistan.

Molecular detection of ESBL and carbapenemase encoding genes

DNA extraction of ESBL positive E. coli was done using commercially available GeneJET Genomic Kit (Thermo Scientific, UK). ESBL encoding genes; $b l a_{\mathrm{TEM}}$, bla ${ }_{\mathrm{SHV}}, b_{\text {СТХ-M, }}$ bla $a_{\mathrm{OXA},}$ and Carbapenemase encoding genes bla ${ }_{\mathrm{IMP},}$ bla $a_{\mathrm{VIM}}$ and $b l a_{\mathrm{NDM}}$ were identified through PCR using specific primers (Table I). Thermocycler conditions for 
Table I. Primers for the detection of ESBL genes.

\begin{tabular}{|c|c|c|c|c|c|}
\hline Gene & Primers & Sequence $\left(5^{\prime}\right.$ to $\left.3^{\prime}\right)$ & $\begin{array}{l}\text { Annealing } \\
\text { temperature }\end{array}$ & $\begin{array}{l}\text { Amplicon } \\
\text { size (bp) }\end{array}$ & References \\
\hline$b l a_{\mathrm{SHV}}$ & $\begin{array}{l}\text { SHV-F } \\
\text { SHV-R }\end{array}$ & $\begin{array}{l}\text { CTTTATCGGCCCTCACTCAA } \\
\text { AGGTGCTCATCATGGGAAAG }\end{array}$ & $62^{\circ} \mathrm{C}$ & 237 & (Fang et al., 2004) \\
\hline$b l a_{\text {TЕM }}$ & $\begin{array}{l}\text { TEM-F } \\
\text { TEM-R }\end{array}$ & $\begin{array}{l}\text { CGCCGCATACACTATTCTCAGAATGA } \\
\text { ACGCTCACCGGCTCCAGATTTAT }\end{array}$ & $62^{\circ} \mathrm{C}$ & 445 & (Monstein et al., 2007) \\
\hline$b^{l} a_{\text {СТХ-M }}$ & $\begin{array}{l}\text { CTX-M-F } \\
\text { CTX-M-R }\end{array}$ & $\begin{array}{l}\text { ATGTGCAGYACCAGTAARGTKATGGC } \\
\text { TGGGTRAARTARGTSACCAGAAYCAGCGG }\end{array}$ & $62^{\circ} \mathrm{C}$ & 593 & (Boyd et al., 2004) \\
\hline$b l a_{\mathrm{OXA}}$ & $\begin{array}{l}\text { OXA-F } \\
\text { OXA-R }\end{array}$ & $\begin{array}{l}\text { ACACAATACATATCAACTTCGC } \\
\text { AGTGTGTTTAGAATGGTGATC }\end{array}$ & $62^{\circ} \mathrm{C}$ & 813 & (Ouellette et al., 1987) \\
\hline $\begin{array}{l}\text { bla }_{\text {CTX-M }} \\
\text { group 1 }\end{array}$ & $\begin{array}{l}\text { CTX-M1-F } \\
\text { CTX-M1-R }\end{array}$ & $\begin{array}{l}\text { AAAAATCACTGCGCCAGTTC } \\
\text { AGCTTATTCATCGCCACGTT }\end{array}$ & $52^{\circ} \mathrm{C}$ & 415 & (Woodford et al., 2006) \\
\hline $\begin{array}{l}\text { bla }_{\text {СТX-M }} \\
\text { group 2 }\end{array}$ & $\begin{array}{l}\text { CTX-M2-F } \\
\text { CTX-M2-R }\end{array}$ & $\begin{array}{l}\text { CGACGCTACCCCTGCTATT } \\
\text { CCAGCGTCAGATTTTTCAGG }\end{array}$ & $52^{\circ} \mathrm{C}$ & 552 & \\
\hline $\begin{array}{l}\text { bla } \\
\text { CrTX-M } \\
\text { group } 9\end{array}$ & $\begin{array}{l}\text { CTX-M9-F } \\
\text { CTX-M9-R }\end{array}$ & $\begin{array}{l}\text { CAAAGAGAGTGCAACGGATG } \\
\text { ATTGGAAAGCGTTCATCACC }\end{array}$ & $52^{\circ} \mathrm{C}$ & & \\
\hline $\begin{array}{l}\text { bla }_{\text {СTX-M }} \\
\text { group } 8\end{array}$ & $\begin{array}{l}\text { CTX-M8-F } \\
\text { CTX-M8-R }\end{array}$ & $\begin{array}{l}\text { TCGCGTTAAGCGGATGATGC } \\
\text { AACCCACGATGTGGGTAGC }\end{array}$ & & 666 & \\
\hline $\begin{array}{l}\text { bla }_{\text {CTX-M }} \\
\text { group25 }\end{array}$ & $\begin{array}{l}\text { CTX-M25-F } \\
\text { CTX-M25-R }\end{array}$ & $\begin{array}{l}\text { GCACGATGACATTCGGG } \\
\text { AACCCACGATGTGGGTAGC }\end{array}$ & & 327 & \\
\hline$b l a_{\mathrm{IMP}}$ & $\begin{array}{l}\text { IMP-F } \\
\text { IMP-R }\end{array}$ & $\begin{array}{l}\text { GGAATAGAGTGGCTTAAYTCTC } \\
\text { GGTTTAAYAAAACAACCAC }\end{array}$ & & 232 & (Poirel et al., 2011) \\
\hline$b l a_{\mathrm{VIM}}$ & $\begin{array}{l}\text { VIM-F } \\
\text { VIM-R }\end{array}$ & $\begin{array}{l}\text { GATGGTGTTTGGTCGCATA } \\
\text { CGAATGCGCAGCACCAG }\end{array}$ & $52^{\circ} \mathrm{C}$ & 390 & \\
\hline$b l a_{\mathrm{NDM}}$ & $\begin{array}{l}\text { NDM-F } \\
\text { NDM-R }\end{array}$ & $\begin{array}{l}\text { GGTTTGGCGATCTGGTTTTC } \\
\text { CGGAATGGCTCATCACGATC }\end{array}$ & $52^{\circ} \mathrm{C}$ & 621 & \\
\hline
\end{tabular}

Table II. Prevalence of $E$. coli and phenotypic confirmation of ESBL $E$. coli isolates from different sources.

\begin{tabular}{llcl}
\hline Sample Sources & $\begin{array}{l}\text { Number of } \\
\text { samples }\end{array}$ & E. coli n (\%) & $\begin{array}{l}\text { ESBL producing- } \\
\text { E. coli isolates n (\%) }\end{array}$ \\
\hline Environmental samples Water (poultry drinking water) & 23 & $9(39.1 \%)$ & $4(44.4 \%)$ \\
Wastewater & 38 & $30(78.9 \%)$ & $23(76.6 \%)$ \\
Community sewage & 31 & $24(77.4 \%)$ & $15(62.5 \%)$ \\
Subtotal & 92 & $63(68.4 \%)$ & $42(66.6 \%)$ \\
Poultry (Chicken ceca) & 250 & $213(85.2 \%)$ & $156(73.2 \%)$ \\
Urine (poultry farm workers) & 50 & $27(54 \%)$ & $21(77.7 \%)$ \\
Grand total & 392 & $303(77.2 \%)$ & $219(72.2 \%)$ \\
\hline
\end{tabular}

ESBL encoding genes were; an initial denaturation for 5 min at $95^{\circ} \mathrm{C}$; followed by 36 cycles at $95^{\circ} \mathrm{C}$ for the $30 \mathrm{sec}$, $62^{\circ} \mathrm{C}$ for $90 \mathrm{sec}$, and $72^{\circ} \mathrm{C}$ for $60 \mathrm{sec}$; with a final extension for $10 \mathrm{~min}$ at $72^{\circ} \mathrm{C}$ and for carbapenemase encoding genes were; an initial denaturation for 10 minutes at $94^{\circ} \mathrm{C}$ and 36 cycles of amplification consisting of $30 \mathrm{~s}$ at $94^{\circ} \mathrm{C}, 40$ $\mathrm{s}$ at $52^{\circ} \mathrm{C}$, and $50 \mathrm{~s}$ at $72^{\circ} \mathrm{C}$, with 5 minutes at $72^{\circ} \mathrm{C}$ for the final extension. Gel electrophoresis of the amplified product was determined by $1.5 \%$ agarose gel and bands were visualized under UV light in the Gel Documentation instrument (Bio-Rad, UK) (Woodford et al., 2006).
Multiplex PCR for genotypic profiling of the bla ${ }_{C T X-M}$ group Genotypic detection of the bla ${ }_{\text {СТХ-M }}$ group $(1,2,9,8$ and 25) was performed through multiplex PCR using specific primers (Table I). Thermocycler conditions were as follows; an initial denaturation for $5 \mathrm{~min}$ at $94^{\circ} \mathrm{C}$; followed by 30 cycles for $25 \mathrm{sec}$ at $94^{\circ} \mathrm{C}$, for the $40 \mathrm{sec}$ at $52^{\circ} \mathrm{C}$ and for $50 \mathrm{sec}$ at $72^{\circ} \mathrm{C}$; with a final extension for $6 \mathrm{~min}$ at $72^{\circ} \mathrm{C}$. Gel electrophoresis of the amplified product was determined by $1.5 \%$ agarose gel and bands were visualized under UV light in the Gel Documentation instrument (BioRad, UK) (Woodford et al., 2006). 
Antimicrobial susceptibility testing

Antibiogram was performed by Kirby-Bauer disc diffusion method using Mueller-Hinton agar (MHA) (Oxoid, UK) as per CLSI 2018 guidelines. The tested antibiotics were as followed; cefotaxime $(30 \mu \mathrm{g})$, ceftazidime $(30 \mu \mathrm{g})$, cefixime $(5 \mu \mathrm{g})$, ceftriaxone $(30 \mu \mathrm{g})$, cefepime $(30 \mu \mathrm{g})$, cefotaxime/clavulanic acid $(30 / 10 \mu \mathrm{g})$, ceftazidime/clavulanic acid $(30 / 10 \mu \mathrm{g})$, amoxicillin/ clavulanic acid $(30 / 10 \mu \mathrm{g})$, piperacillin/tazobactam $(110 \mu \mathrm{g})$ ciprofloxacin $(5 \mu \mathrm{g})$, aztreonam $(30 \mu \mathrm{g})$, imipenem $(10 \mu \mathrm{g})$, meropenem $(10 \mu \mathrm{g})$, gentamycin $(10 \mu \mathrm{g})$, amikacin $(30 \mu \mathrm{g})$, trimethoprim/sulfamethoxazole $(25 \mu \mathrm{g})$ and colistin $(10 \mu \mathrm{g})$. Interpretation of the zone of inhibition was carried out according to CLSI 2018 guidelines. (Weinstein et al., 2018) ESBL-negative (E. coli ATCC 25922) and ESBL-positive (K. pneumonia ATCC 700603) strains were used as quality control for all the research processes. The minimum inhibitory concentration of the selected antimicrobial agents was also determined by the broth dilution method. The MIC of the ceftriaxone, cefotaxime, ceftazidime, cefepime, imipenem, ciprofloxacin, and colistin, was evaluated and the results were interpreted according to CLSI 2018 guidelines.

\section{RESULTS}

\section{E. coli and ESBL producing E. coli isolates}

A total of 213 E. coli isolates were recovered from chicken ceca, 63 from the environment and 27 were recovered from urine samples. Of 213 chicken E. coli, $156(73.2 \%)$ were confirmed as ESBL producers, 63 environmental E. coli, $42(66.6 \%)$ and 27 urinary $E$. coli, $21(77.7 \%)$ were confirmed as ESBL producing isolates determined by combination disc diffusion method. Overall, 219 (72.2\%) ESBL-producing E. coli isolates were phenotypically confirmed from $303 \mathrm{E}$. coli isolates. Prevalence of ESBL producing E. coli isolates from different water samples varied as $44 \%$ from poultry drinking water, $76.6 \%$ from poultry wastewater and 62.5 $\%$ from community sewage as shown in Table II.

\section{Prevalence of ESBL and carbapenemase encoding genes}

The ESBL producing $E$. coli isolates were further examined for the presence of ESBL-encoding genes as well as for the detection of bla $a_{\text {СТХ-M }}$ groups and the results are shown in Table III. Our results showed that, of 219 bla ${ }_{\text {СTХ-M, }}$ $156(71.2 \%)$ were isolated from poultry samples, $42(19.1 \%)$ from water samples and $21(9.6 \%)$ from urine samples. However, of 194 bla $_{\text {CTX-M-1, }} 131$ (67.5\%), 42 (21.6\%) and $21(10.8 \%)$ were isolated from poultry water and urine samples, respectively followed by $19(100 \%)$ of $b l a_{\text {СТХ-М-2, }}$ $b l a_{\text {CTX-M-8 }}$ and $27(100 \%)$ of bla $a_{\text {CTX-M-9 }}$ were only isolated from poultry samples. Most of these isolates were identified from a different region of Islamabad. The combination of $b l a_{\text {СTX-М-2 }}$ $b l a_{\text {СТХ-м-8 }} / b l a_{\text {СТХ-М-9 }}$ producing E. coli $(\mathrm{n}=16 ; 100 \%)$ was only isolated from poultry samples. Of $114 \mathrm{bla}_{\mathrm{TEM}}$ producing $E$. coli, $71(62.2 \%), 42(36.8 \%)$ and $1(0.8 \%)$ were recovered from poultry, water, and urine samples respectively. However, $28 \mathrm{bla}_{\mathrm{SHV}}$ producing $E$. coli were only isolated from poultry samples and of 12 bla $_{\mathrm{OXA}}, 9(75 \%)$ were isolated from poultry, $2(16.7 \%)$ from urine and $1(8.3 \%)$ from the water samples. Co-existence of $b l a_{\mathrm{CTX}-\mathrm{M}} / b l a_{\mathrm{TEM}} / b l a_{\mathrm{SHV}}$ was identified in the $E$. coli recovered from poultry samples $(\mathrm{n}=3 ; 100 \%)$. Of 4 $b l a_{\mathrm{CTX}-\mathrm{M}} / b l a_{\mathrm{TEM}} / b l a_{\mathrm{OXA}}$ combination, $2(50 \%)$ were isolated from poultry $1(25 \%)$ from water and $1(25 \%)$ from urine samples. In addition, carbapenemase encoding genes were also detected in E. coli isolates as represented in Table III. Of 21 bla $_{\mathrm{IMP}} 16(76.1 \%)$ were detected from poultry, $3(14.2 \%)$ from both water and urine samples. While $47 b l a_{\mathrm{VIM}}, 36$ (76.5\%) were recovered from poultry, $8(17 \%)$ and $3(6.3 \%)$ from urine and water samples, respectively. However, of 34 bla $_{\mathrm{NDM}}$ producing E. coli, 31 (91.1\%) and 3 (8.8\%) were only isolated from poultry and urine samples, respectively. The co-existence of carbapenemase encoding genes was also observed in $E$. coli isolates as bla $\mathrm{IMP}_{\mathrm{IM}} / \operatorname{bla}_{\mathrm{VIM}}(\mathrm{n}=4)$ were recovered from poultry and water samples, $b l a_{\mathrm{VIM}} / b l a_{\mathrm{NDM}}$ $(\mathrm{n}=21)$ were recovered from chicken and urine samples and bla $a_{\mathrm{IMP}} / b l a_{\mathrm{VIM}} / b l a_{\mathrm{NDM}}(\mathrm{n}=14)$ was also observed in isolates from chicken and urine samples.

\section{Antimicrobial susceptibility testing}

All these 219 isolates were further evaluated against various antimicrobials as shown in Table IV. The isolates displayed $100 \%$ resistance to cephalosporins, amoxicillin/ clavulanic acid and aztreonam followed by $86.7 \%$ to trimethoprim/ sulfamethoxazole, $75.3 \%$ to ciprofloxacin, $58.4 \%$ to piperacillin/tazobactam, $42.9 \%$ to gentamycin and amikacin, $23.7 \%$ to meropenem and $23.2 \%$ to imipenem. Colistin was found as the most susceptible drug by displaying the lowest resistance (17.8\%) against ESBL-producing E. coli isolates. Further, the minimum inhibitory concentration for cefotaxime against ESBL $E$. coli isolates was $256 \mu \mathrm{g} / \mathrm{ml}(12.3 \%) \geq 256 \mu \mathrm{g} / \mathrm{ml}(87.6 \%)$, for ceftriaxone was $256 \mu \mathrm{g} / \mathrm{ml}(10.9 \%) \geq 256 \mu \mathrm{g} / \mathrm{ml}$ (89\%), for ceftazidime was $128 \mu \mathrm{g} / \mathrm{ml}(9.1 \%) \geq 256 \mu \mathrm{g} / \mathrm{ml}$ $(87 \%)$ and for cefepime was $128 \mu \mathrm{g} / \mathrm{ml}(9.4 \%) \geq 256 \mu \mathrm{g} /$ $\mathrm{ml}(83 \%)$. The MIC range was $0.25 \mu \mathrm{g} / \mathrm{ml}(10 \%) \geq 256 \mu \mathrm{g} /$ $\mathrm{ml}(5 \%)$ for imipenem. The $50(22.8 \%)$ out of 219 isolates were sensitive to ciprofloxacin with a MIC $<0.25 \mu \mathrm{g} / \mathrm{ml}$. $4(1.8 \%)$ of the isolates were intermediate having a MIC of $0.5 \mu \mathrm{g} / \mathrm{ml}$. The majority of ESBL $E$. coli strains i.e. 111 $(50.6 \%)$ exhibit a MIC of $64 \mu \mathrm{g} / \mathrm{ml}$ for ciprofloxacin. The MIC range of the ESBL E. coli isolates for colistin was $0.25 \mu \mathrm{g} / \mathrm{ml}(34.7 \%)-8 \mu \mathrm{g} / \mathrm{ml}(2.2 \%)$ as shown in Table V. 
Table III. Prevalence of ESBL- producing genes among $E$. coli isolates recovered from poultry and environmental (water) samples.

\begin{tabular}{|c|c|c|c|c|}
\hline ESBL Ggenotype & Total No. of ESBL genes & Poultry & Water & Poultry farmworkers \\
\hline$b l a_{\text {СТХ-M }}$ & 219 & $156(71.2 \%)$ & $42(19.1 \%)$ & $21(9.6 \%)$ \\
\hline bla $_{\text {СТХ-M-1 }}$ & 194 & $131(67.5 \%)$ & $42(21.6 \%)$ & $21(10.8 \%)$ \\
\hline$b l a_{\text {СТХ-M-2 }}$ & 19 & $19(100 \%)$ & $0(0 \%)$ & $0(0 \%)$ \\
\hline$b l a_{\text {СТХ-M-8 }}$ & 19 & $19(100 \%)$ & $0(0 \%)$ & $0(0 \%)$ \\
\hline$b l a_{\text {СТХ-М-9 }}$ & 27 & $27(100 \%)$ & $0(0 \%)$ & $0(0 \%)$ \\
\hline$b l a_{\mathrm{CTX}-\mathrm{M}-1}+b l a_{\text {СTХ-M-2 }}$ & 1 & $1(100 \%)$ & $0(0 \%)$ & $0(0 \%)$ \\
\hline$b l a_{\text {СТХ-M-1 }}+b l a_{\text {СТХ-М-8 }}$ & 1 & $1(100 \%)$ & $0(0 \%)$ & $0(0 \%)$ \\
\hline$b l a_{\text {СТХ-М-1 }}+b l a_{\text {СТХ-М-9 }}$ & 2 & $2(100 \%)$ & $0(0 \%)$ & $0(0 \%)$ \\
\hline$b l a_{\text {СТХ-M-2 }}+b l a_{\text {СТХ-М-8 }}$ & 16 & $16(100 \%)$ & $0(0 \%)$ & $0(0 \%)$ \\
\hline$b l a_{\text {СТХ-M-2 }}+b l a_{\text {СТХ-М-9 }}$ & 18 & $18(100 \%)$ & $0(0 \%)$ & $0(0 \%)$ \\
\hline$b l a_{\text {СТХ-М-8 }}+b l a_{\text {СТХ-M-9 }}$ & 18 & $18(100 \%)$ & $0(0 \%)$ & $0(0 \%)$ \\
\hline$b l a_{\text {СТХ-М- } 2}+b l a_{\text {СТХ-М-8 }}+b l a_{\text {СТХ-М-9 }}$ & 16 & $16(100 \%)$ & $0(0 \%)$ & $0(0 \%)$ \\
\hline$b l a_{\mathrm{TEM}}$ & 114 & $71(62.2 \%)$ & $42(36.8 \%)$ & $1(0.8 \%)$ \\
\hline$b l a_{\mathrm{SHV}}$ & 28 & $28(100 \%)$ & $0(0 \%)$ & $0(0 \%)$ \\
\hline$b l a_{\mathrm{OXA}}$ & 12 & $9(75 \%)$ & $1(8.3 \%)$ & $2(16.7 \%)$ \\
\hline$b l a_{\mathrm{CTX}^{-\mathrm{M}}+} b l a_{\mathrm{TEM}^{+}} b l a_{\mathrm{SHV}}$ & 3 & $3(100 \%)$ & $0(0 \%)$ & $0(0 \%)$ \\
\hline$b l a_{\mathrm{CTX}-\mathrm{M}+} b l a_{\mathrm{TEM}^{+}} b l a_{\mathrm{OXA}}$ & 4 & $2(50 \%)$ & $1(25 \%)$ & $1(25 \%)$ \\
\hline$b l a_{\mathrm{IMP}}$ & 21 & $16(76.1 \%)$ & $3(14.2 \%)$ & $3(14.2 \%)$ \\
\hline$b l a_{\mathrm{VIM}}$ & 47 & $36(76.5 \%)$ & $3(6.3 \%)$ & $8(17 \%)$ \\
\hline$b l a_{\mathrm{NDM}}$ & 34 & $31(91.1 \%)$ & $0(0 \%)$ & $3(8.8 \%)$ \\
\hline$b l a_{\mathrm{IMP}}+b l a_{\mathrm{VIM}}$ & 4 & $2(50 \%)$ & $2(50 \%)$ & $0(0 \%)$ \\
\hline$b l a_{\mathrm{VIM}}+b l a_{\mathrm{NDM}}$ & 21 & $18(85.7 \%)$ & $0(0 \%)$ & $3(14.2 \%)$ \\
\hline$b l a_{\mathrm{IMP}}+b l a_{\mathrm{VIM}}+b l a_{\mathrm{NDM}}$ & 14 & $13(92.8 \%)$ & $0(0 \%)$ & $1(7.1 \%)$ \\
\hline
\end{tabular}

Table IV. Antimicrobial susceptibility pattern of ESBL $E$. coli isolates.

\begin{tabular}{|c|c|c|c|c|c|c|}
\hline Antimicrobial classes & Antimicrobials & Abb. & $\begin{array}{l}\text { Concentration } \\
(\mu \mathrm{g})\end{array}$ & $\begin{array}{l}\text { Sensitive } \\
\%\end{array}$ & $\begin{array}{l}\text { Intermediate } \\
\%\end{array}$ & $\begin{array}{l}\text { Resistance } \\
\%\end{array}$ \\
\hline $1^{\text {st }}$ generation cephalosporin & Cephradine & $\mathrm{CE}$ & 30 & 0 & 0 & 100 \\
\hline \multicolumn{2}{|c|}{$3^{\text {rd }}$ generation cephalosporin Cefotaxime } & CTX & 30 & 0 & 0 & 100 \\
\hline & Ceftazidime & $\mathrm{CAZ}$ & 30 & 0 & 13.2 & 86.7 \\
\hline & Ceftriaxone & CRO & 30 & 0 & 0 & 100 \\
\hline & Cefixime & CFM & 5 & 1.3 & 2.7 & 95.8 \\
\hline $4^{\text {th }}$ generation cephalosporin & Cefepime & FEP & 30 & 0 & 7.7 & 92.2 \\
\hline \multirow{2}{*}{$\begin{array}{l}\beta \text { - lactamase inhibitors com- } \\
\text { bination with cephalosporin }\end{array}$} & Cefotaxime/ Clavulanic acid & CTL & $30 / 10$ & 2.2 & 7.3 & 90.4 \\
\hline & Ceftazidime/ Clavulanic acid & CAL & $30 / 10$ & 24.6 & 0.4 & 74.8 \\
\hline \multirow{2}{*}{$\begin{array}{l}\beta \text { - lactamase inhibitors com- } \\
\text { bination with Penicillin }\end{array}$} & Amoxicillin/ Clavulanic acid & $\mathrm{AMC}$ & $30 / 10$ & 0 & 0 & 100 \\
\hline & Piperacillin/ tazobactam & $\mathrm{TZP}$ & 110 & 34.7 & 6.8 & 58.4 \\
\hline \multirow{2}{*}{ Carbapenems } & Imipenem & IPM & 10 & 67.1 & 9.6 & 23.2 \\
\hline & Meropenem & MEM & 10 & 66.6 & 9.6 & 23.7 \\
\hline Monobactam & Aztreonam & ATM & 30 & 0 & 1.8 & 98.1 \\
\hline Fluoroquinolones & Ciprofloxacin & CIP & 5 & 22.8 & 1.8 & 75.3 \\
\hline \multirow[t]{2}{*}{ Aminoglycosides } & Gentamycin & $\mathrm{CN}$ & 10 & 50.2 & 6.8 & 42.9 \\
\hline & Amikacin & $\mathrm{AK}$ & 30 & 50.2 & 6.8 & 42.9 \\
\hline Folate pathway inhibitors & Trimethoprim/Sulfamethoxazole & SXT & 25 & 13.2 & 0 & 86.7 \\
\hline Polymyxins & Colistin & $\mathrm{CT}$ & 10 & 83.8 & 0 & 17.8 \\
\hline
\end{tabular}


Table V. Minimum inhibitory concentration of ESBL $E$. coli isolates.

\begin{tabular}{llllllll}
\hline $\begin{array}{l}\text { MIC } \\
(\boldsymbol{\mu g})\end{array}$ & $\begin{array}{l}\text { Cefotaxime } \\
(\mathbf{C T X})\end{array}$ & $\begin{array}{l}\text { Ceftazidime } \\
(\mathbf{C A Z})\end{array}$ & $\begin{array}{l}\text { Ceftriaxone } \\
(\mathbf{C R O})\end{array}$ & $\begin{array}{l}\text { Cefepime } \\
(\text { FEP) }\end{array}$ & $\begin{array}{l}\text { Imipenem } \\
(\text { IPM) }\end{array}$ & $\begin{array}{l}\text { Ciprofloxacin } \\
(\mathbf{C I P})\end{array}$ & $\begin{array}{l}\text { Colistin } \\
(\mathbf{C T})\end{array}$ \\
\hline 0.25 & $0(0 \%)$ & $0(0 \%)$ & $0(0 \%)$ & $0(0 \%)$ & $22(10 \%)$ & $50(22.8 \%)$ & $76(34.7 \%)$ \\
0.5 & $0(0 \%)$ & $0(0 \%)$ & $0(0 \%)$ & $0(0 \%)$ & $78(36 \%)$ & $4(1.8 \%)$ & $80(36.5 \%)$ \\
1 & $0(0 \%)$ & $0(0 \%)$ & $0(0 \%)$ & $0(0 \%)$ & $47(21 \%)$ & $0(0 \%)$ & $24(10.9 \%)$ \\
2 & $0(0 \%)$ & $0(0 \%)$ & $0(0 \%)$ & $0(0 \%)$ & $21(10 \%)$ & $0(0 \%)$ & $2(0.9 \%)$ \\
4 & $0(0 \%)$ & $0(0 \%)$ & $0(0 \%)$ & $0(0 \%)$ & $0(0 \%)$ & $0(0 \%)$ & $32(14.6 \%)$ \\
8 & $0(0 \%)$ & $0(0 \%)$ & $0(0 \%)$ & $0(0 \%)$ & $3(1.3 \%)$ & $12(5.4 \%)$ & $5(2.2 \%)$ \\
16 & $0(0 \%)$ & $0(0 \%)$ & $0(0 \%)$ & $0(0 \%)$ & $5(2.2 \%)$ & $6(2.7 \%)$ & $0(0 \%)$ \\
32 & $0(0 \%)$ & $0(0 \%)$ & $0(0 \%)$ & $0(0 \%)$ & $8(3.6 \%)$ & $21(9.5 \%)$ & $0(0 \%)$ \\
64 & $0(0 \%)$ & $0(0 \%)$ & $0(0 \%)$ & $0(0 \%)$ & $8(3.6 \%)$ & $111(50.6 \%)$ & $0(0 \%)$ \\
128 & $0(0 \%)$ & $20(9.1 \%)$ & $0(0 \%)$ & $17(9.4 \%)$ & $7(3.1 \%)$ & $0(0 \%)$ & $0(0 \%)$ \\
256 & $27(12.3 \%)$ & $9(4.1 \%)$ & $24(10.9 \%)$ & $21(9.5 \%)$ & $9(4.1 \%)$ & $7(3.1 \%)$ & $0(0 \%)$ \\
$>256$ & $192(87.6 \%)$ & $190(87 \%)$ & $195(89 \%)$ & $181(83 \%)$ & $11(5 \%)$ & $8(3.6 \%)$ & $0(0 \%)$ \\
Total & 219 & 219 & 219 & 219 & $219 \%)$ & 219 \\
\hline
\end{tabular}

\section{DISCUSSION}

The emergence of resistance in E. coli against cephalosporins is of major concern in human as well as veterinary medicine because cephalosporins are widely used in human healthcare settings (Dierikx et al., 2010). In Pakistan, the urge to optimize animal production has led to the unselective use of antibiotics. The irrational use of antibiotics is evaluated as an imperative predisposing factor for the attainment of ESBL producing bacteria consequently increasing resistance to frequently used drugs such as erythromycin, ampicillin, gentamicin, tetracycline, cotrimoxazole, and third-generation cephalosporins (Reich et al., 2013). Our study has shown an overall prevalence of $73.2 \%, 77.7 \%$ and $66.6 \%$ of ESBL producing E. coli from chicken ceca, urine from poultry farmworkers and environmental water respectively. These findings agree with the previous study published in Egypt with a $65 \%$ prevalence of ESBL producing E. coli from poultry (Abdallah et al., 2015; Hiroi et al., 2011). However, a study from Pakistan revealed a low prevalence of ESBL producing $E$. coli from poultry meat $(47.6 \%)$ and poultry water (38.8\%) (Rahman et al., 2018). In another study published from Korea in which 44 and $68 \mathrm{E}$. coli isolates from poultry and swine, farmworkers were recovered, respectively (Cho et al., 2012). The high prevalence in our study might be due to recurrent administration of antibiotics to poultry which in turn increases the risk of highly resistant $E$. coli strains in the normal flora of intestine as reported in a study which evaluated that food animal was likely reservoir for antimicrobial-resistant fecal flora particularly E. coli (Carattoli, 2008).
The present study showed that $b l a_{\text {Стхм }}$ remained a predominant genotype among all the ESBL-producing $E$. coli isolated from poultry, environment, and urine. These findings are in accordance with other previous studies from Pakistan (Abrar et al., 2017; Khan et al., 2010) and India (Upadhyay et al., 2015). They strongly suggested that $b l a_{\text {СТХ-М }}$ is the most dominant genotype of ESBL in Asia. Analysis of $\beta$-lactamase genes in our study revealed that all the isolates from poultry carried bla $a_{\text {CTX-M }}$ followed by bla $a_{\mathrm{TEM}}$, bla $_{\mathrm{SHV}}$ and $b l a_{\mathrm{OXA}}$ (Table III). These findings are in line with the previous studies from Japan (Kawamura et al., 2014) and Brazil (Nogueira et al., 2015). The high prevalence of $b l a_{\text {СтХ-М }}$ producing $E$. coli might be attributable to the increased growth of indigenous strains harboring $b l a_{\text {СTX-M }}$ and there is a possibility for the emergence of $b l a_{\text {СтХ-м }}$ producing strains by horizontal transfer on different farms. Furthermore, the ESBL positive $E$. coli in the existing study also carried multiple types of ESBL genotypes and a combination of $b l a_{\mathrm{CTX}-\mathrm{M}} / b l a_{\mathrm{TEM}}$ was predominant, followed by $b l a_{\text {CTX-M }} / b l a_{\text {SHV }}, b l a_{\text {СTX-M }} /$ $b l a_{\text {OXA. }}$ This type of co-existence of ESBL genes was also observed in a study from Turkey (Tekiner and Ozpinar, 2016). These findings consequently confirmed that ESBLmediated plasmids can carry multiple $\beta$-lactamase genes and these determinants are easily transportable to other bacteria of the same genre or of different genres within Enterobacteriaceae (Giedraitiene et al., 2011). In the current study, the $b l a_{\text {CTX-М-1 }}$ was the most prevalent in poultry, environment and urine accounted for $67.5 \%$, $21.6 \%$, and $10.8 \%$ respectively. The $b l a_{\text {СтХ-м-2 }}(100 \%)$, bla $a_{\text {СТХ-М-8 }}(100 \%)$, and bla $a_{\text {СтХ-м-9 }}(100 \%)$ were only observed in poultry. A study from Austria has reported that 
bla $a_{\text {СТХ-M-1 }}$ were the predominant genes in ESBL producing E. coli recovered from chicken meat (Zarfel et al., 2014). In contrast, a study from Japan has established that the most prevalent genes were $b l a_{\text {CTX-M-9 }}(67 \%)$, bla $a_{\text {СTХ-M-1 }}$ (19\%) and bla $a_{\text {СтХ-м-2 }}(5.8 \%)$ among ESBL producing $E$. coli (Chong et al., 2013).

These findings suggested a serious threat to public health and an important food safety concern because the retail meat could be a source for drug-resistant bacterial strains that ultimately can be transmitted to humans. In addition, carbapenemase-producing genes as 9.6\% (19/219) $b l a_{\mathrm{IMP}}$ and $21.4 \%(47 / 219) b l a_{\mathrm{VIM}}$ were also detected from poultry, urine, and environmental samples, whereas $15.5 \%(34 / 219) b l a_{\mathrm{NDM}}$ was recovered only from chicken and urine samples. Also, the co-existence of multiple carbapenemase encoding genes was observed in $E$. coli isolates as the combination of bla $a_{\mathrm{IMP}} / b l a_{\mathrm{VIM}}(2 \%), b l a_{\mathrm{VIM}} /$ $b l a_{\mathrm{NDM}}(9.5 \%)$ and $b l a_{\mathrm{IMP}} / b l a_{\mathrm{VIM}} / b l a_{\mathrm{NDM}}(6.4 \%)$. These results are in agreement with a recent study from Pakistan as they isolated $b l a_{\mathrm{VIM}}$ and $b l a_{\mathrm{NDM}}$ producing E. coli strain from poultry meat (Younas et al., 2019). Whereas, some previous studies reported from Pakistan suggested that bla $a_{\mathrm{NDM}}$ was a prominent gene in the community (Sartor et $a l ., 2014$ ) and clinical settings (Hussain, 2015; Perry et al., 2011; Sattar et al., 2016). Identification of carbapenemase encoding genes, particularly NDM in E. coli isolates recovered from poultry is alarming representing that NDM has been widespread distribution among both animals as well as humans. In the present study, ESBL producing $E$. coli showed a high level of resistance to $\beta$-lactam and $\beta$-lactam inhibitors, trimethoprim/sulfamethoxazole, ciprofloxacin, and aminoglycosides. These findings are in agreement with the previously published studies from Tanzania (Mshana et al., 2009), Zambia (Chishimba et al., 2016), and Thailand (Runcharoen et al., 2017) that reported a high level of drug resistance. In our settings, the high level of resistance is mainly due to the irrational use of antibiotics in the poultry industry, misuse of antibiotics, broad-spectrum antibiotics and availability of antibiotics over the counter (Qamar et al., 2014; Rahman et al., 2018).

\section{CONCLUSION}

It was concluded that a high prevalence of ESBL producing $E$. coli isolates in poultry, poultry farmworkers and environmental water was found in twin cities, Pakistan. Moreover, all the isolates were resistant to commonly used antibiotics confirming that poultry might be one of the significant and possible reservoirs for the multidrug and ESBL resistant genes which could spread into the food chain. The risk of zoonotic transmission from poultry to persons with close contact is still largely unknown, however, the data obtained imply that occupational exposure to ESBL E. coli strains from animal contact in the poultry industry might be a significant route of transmission of resistant $E$. coli into the community. As per our knowledge, there is no data available on ESBL encoding genes especially among the bacterial isolates from poultry workers in Pakistan. Therefore, there is an urgent need for continuous surveillance to obtain data that will help formulate appropriate antibiotic policies to manage the growing drug resistance problem.

\section{ACKNOWLEDGMENTS}

We are thankful to Dr. Amir Bin Zahoor (Director General), Dr. Muhammad Abubaker (Senior Scientific Officer), Dr. Shumaila Manzoor (Laboratory Technologist) and Mr. Eid Nawaz Khan (Laboratory Technologist) for their guidance and support. This work was supported by the World Health Organization for Global Tricycle project on ESBL positive E. coli and partially by the grant from the National Veterinary Laboratory, Ministry of Food and Security.

\section{Statement of conflict of interest}

The authors have declared no conflict of interest.

\section{REFERENCES}

Abdallah, H., Reuland, E., Wintermans, B., Al Naiemi, N., Koek, A., Abdelwahab, A., Ammar, A., Mohamed, A. and Vandenbroucke-Grauls, C., 2015. Extended-spectrum $\beta$-lactamases and/ or carbapenemases-producing Enterobacteriaceae isolated from retail chicken meat in Zagazig, Egypt. PLoS One, 10: e0136052. https://doi.org/10.1371/ journal.pone.0136052

Abraham, S., Chapman, T.A., Zhang, R., Chin, J., Mabbett, A.N., Totsika, M. and Schembri, M.A., 2012. Molecular characterization of Escherichia coli strains that cause symptomatic and asymptomatic urinary tract infections. J. clin. Microbiol., 50: 1027-1030. https://doi.org/10.1128/ JCM.06671-11

Abrar, S., Vajeeha, A., Ul-Ain, N. and Riaz, S., 2017. Distribution of CTX-M group I and group III beta-lactamases produced by Escherichia coli and Klebsiella pneumoniae in Lahore, Pakistan. Microb. Pathog., 103: 8-12. https://doi.org/10.1016/j. micpath.2016.12.004

Ahmad, K., Khattak, F., Ali, A., Rahat, S., Noor, S., Mahsood, N. and Somayya, R. 2018. Carbapenemases and extended-spectrum 
beta-lactamase-producing multidrug-resistant Escherichia coli Isolated from retail chicken in Peshawar: First report from Pakistan. J. Fd. Protec., 81: 1339-1345. https://doi.org/10.4315/0362-028X. JFP-18-045

Aslam, B., Wang, W., Arshad, M.I., Khurshid, M., Muzammil, S., Rasool, M.H., Nisar, M.A., Alvi, R.F., Aslam, M.A., Qamar, M.U., Salamat, M.K.F. and Baloch, Z., 2018. Antibiotic resistance: A rundown of a global crisis. Infect. Drug. Resist., 11: 1645-1658. https://doi.org/10.2147/IDR.S173867

Beninati, C., Reich, F., Muscolino, D., Giarratana, F., Panebianco, A., Klein, G. and Atanassova, V., 2015. ESBL-producing bacteria and MRSA isolated from poultry and turkey products imported from Italy. Czech J. Fd. Sci., 33: 97-102. https://doi. org/10.17221/428/2014-CJFS

Boyd, D.A., Tyler, S., Christianson, S., McGeer, A., Muller, M.P., Willey, B.M., Bryce, E., Gardam, M., Nordmann, P. and Mulvey, M.R., 2004. Complete nucleotide sequence of a 92-kilobase plasmid harboring the CTX-M-15 extended-spectrum betalactamase involved in an outbreak in long-term-care facilities in Toronto, Canada. Antimicrob. Agents Chemother., 48: 3758-3764. https://doi.org/10.1128/ AAC.48.10.3758-3764.2004

Brogan, D.M. and Mossialos, E., 2016. A critical analysis of the review on antimicrobial resistance report and the infectious disease financing facility. Glob. Hlth., 12: 8. https://doi.org/10.1186/s12992-016-0147-y

Canton, R., Akova, M., Carmeli, Y., Giske, C.G., Glupczynski, Y., Gniadkowski, M., Livermore, D.M., Miriagou, V., Naas, T., Rossolini, G.M., Samuelsen, O., Seifert, H., Woodford, N., Nordmann, P. and Carbapenemases, E.N., 2012. Rapid evolution and spread of carbapenemases among Enterobacteriaceae in Europe. Clin. Microbiol. Infect., 18: 413-431. https://doi.org/10.1111/j.1469-0691.2012.03821.x

Carattoli, A., 2008. Animal reservoirs for extended spectrum beta-lactamase producers. Clin. Microbiol. Infect., 14 Suppl 1: 117-123. https://doi.org/10.1111/ j.1469-0691.2007.01851.x

Chishimba, K., Hang'ombe, B.M., Muzandu, K., Mshana, S.E., Matee, M.I., Nakajima, C. and Suzuki, Y., 2016. Detection of extended-spectrum betalactamase-producing Escherichia coli in marketready chickens in Zambia. Int. J. Microbiol., 2016: 5275724. https://doi.org/10.1155/2016/5275724

Cho, S.H., Lim, Y.S. and Kang, Y.H., 2012. Comparison of antimicrobial resistance in Escherichia coli strains isolated from healthy poultry and swine farm workers using antibiotics in Korea. Osong
Publ. Hlth. Res. Perspect., 3: 151-155. https://doi. org/10.1016/j.phrp.2012.07.002

Chong, Y., Shimoda, S., Yakushiji, H., Ito, Y., Miyamoto, T., Kamimura, T., Shimono, N. and Akashi, K., 2013. Community spread of extended-spectrum betalactamase-producing Escherichia coli, Klebsiella pneumoniae and Proteus mirabilis: A long-term study in Japan. J. med. Microbiol., 62: 1038-1043. https://doi.org/10.1099/jmm.0.059279-0

Dierikx, C., van Essen-Zandbergen, A., Veldman, K., Smith, H. and Mevius, D., 2010. Increased detection of extended spectrum beta-lactamase producing Salmonella enterica and Escherichia coli isolates from poultry. Vet. Microbiol., 145: 273-278. https:// doi.org/10.1016/j.vetmic.2010.03.019

Fang, H., Lundberg, C., Olsson-Liljequist, B., Hedin, G., Lindback, E., Rosenberg, A. and Struwe, J., 2004. Molecular epidemiological analysis of Escherichia coli isolates producing extended-spectrum betalactamases for identification of nosocomial outbreaks in Stockholm, Sweden. J. clin. Microbiol., 42: $5917-$ 5920. https://doi.org/10.1128/JCM.42.12.59175920.2004

Giedraitiene, A., Vitkauskiene, A., Naginiene, R. and Pavilonis, A., 2011. Antibiotic resistance mechanisms of clinically important bacteria. Medicina-Lithuania, 47: 137-146. https://doi. org/10.3390/medicina47030019

Hiroi, M., Yamazaki, F., Harada, T., Takahashi, N., Iida, N., Noda, Y., Yagi, M., Nishio, T., Kanda, T. and Kawamori, F., 2011. Prevalence of extendedspectrum $\beta$-lactamase-producing Escherichia coli and Klebsiella pneumoniae in food-producing animals. J. Vet. med. Sci., 74: 189-195. https://doi. org/10.1292/jvms.11-0372

Hussain, T., 2015. Pakistan at the verge of potential epidemics by multi-drug resistant pathogenic bacteria. Adv. Life Sci., 2: 46.

Kawamura, K., Goto, K., Nakane, K. and Arakawa, Y., 2014. Molecular epidemiology of extendedspectrum beta-lactamases and Escherichia coli isolated from retail foods including chicken meat in Japan. Foodb. Pathog. Dis., 11: 104-110. https://doi. org/10.1089/fpd.2013.1608

Khan, E., Irfan, S., Sultan, B., Nasir, A. and Hasan, R., 2016. Dissemination and spread of New Delhi metallo-beta-lactamase-1 superbugs in hospital settings. J. Pak. med. Assoc., 66: 999-1004.

Khan, E., Schneiders, T., Zafar, A., Aziz, E., Parekh, A. and Hasan, R., 2010. Emergence of CTX-M group 1-ESBL producing Klebsiella pneumonia from a tertiary care centre in Karachi, Pakistan. J. Infect. 
Dev. Ctries, 4: 472-476. https://doi.org/10.3855/ jidc. 674

Khurshid, M., Rasool, M.H., Ashfaq, U.A., Aslam, B. and Waseem, M., 2017. Emergence of ISAba1 harboring carbapenem-resistant Acinetobacter baumannii isolates in Pakistan. Future Microbiol., 12: 12611269. https://doi.org/10.2217/fmb-2017-0080

Landers, T.F., Cohen, B., Wittum, T.E. and Larson, E.L., 2012. A review of antibiotic use in food animals: Perspective, policy and potential. Publ. Hlth. Rep., 127: 4-22. https://doi. org/10.1177/003335491212700103

Monstein, H.J., Ostholm-Balkhed, A., Nilsson, M.V., Nilsson, M., Dornbusch, K. and Nilsson, L.E., 2007. Multiplex PCR amplification assay for the detection of blaSHV, blaTEM and blaCTX-M genes in Enterobacteriaceae. APMIS, 115: 1400-1408. https://doi.org/10.1111/j.1600-0463.2007.00722.x

Mshana, S.E., Kamugisha, E., Mirambo, M., Chakraborty, T. and Lyamuya, E.F., 2009. Prevalence of multiresistant gram-negative organisms in a tertiary hospital in Mwanza, Tanzania. BMC Res. Notes, 2: 49. https://doi.org/10.1186/1756-0500-2-49

Naas, T., Oueslati, S., Bonnin, R.A., Dabos, M.L., Zavala, A., Dortet, L., Retailleau, P. and Iorga, B.I. 2017. Beta-lactamase database (BLDB) - structure and function. J. Enzyme Inhib. med. Chem., 32:917919. https://doi.org/10.1080/14756366.2017.13442 35

Nogueira, K.D.S., Conte, D., Maia, F.V. and Dalla-Costa, L.M., 2015. Distribution of extended-spectrum $\beta$-lactamase types in a Brazilian tertiary hospital. Rev. Soc. Bras. med. Trop., 48: 162-169. https://doi. org/10.1590/0037-8682-0009-2015

Ouellette, M., Bissonnette, L. and Roy, P.H., 1987. Precise Insertion of antibiotic-resistance determinants into Tn21-like transposons - nucleotide-sequence of the Oxa-1 beta-lactamase gene. Proc. natl. Acad. Sci. U.S.A., 84: 7378-7382. https://doi.org/10.1073/ pnas. 84.21 .7378

Perry, J.D., Naqvi, S.H., Mirza, I.A., Alizai, S.A., Hussain, A., Ghirardi, S., Orenga, S., Wilkinson, K., Woodford, N., Zhang, J., Livermore, D.M., Abbasi, S.A. and Raza, M.W., 2011. Prevalence of faecal carriage of Enterobacteriaceae with NDM-1 carbapenemase at military hospitals in Pakistan, and evaluation of two chromogenic media. J. Antimicrob. Chemother., 66: 2288-2294. https://doi.org/10.1093/ $\mathrm{jac} / \mathrm{dkr} 299$

Poirel, L., Walsh, T.R., Cuvillier, V. and Nordmann, P., 2011. Multiplex PCR for detection of acquired carbapenemase genes. Diagn. Microbiol. Infect.
Dis., 70: 119-123. https://doi.org/10.1016/j. diagmicrobio.2010.12.002

Qamar, M.U., Hannan, A., Arshad, M.U. and Arshad, M., 2014. Metallo-lactamase producing Enterobacter cloacae: An emerging threat in neonates. Afr. $J$. microbiol. Res., 8: 525-528. https://doi.org/10.5897/ AJMR2013.6348

Qamar, M.U., Nahid, F., Walsh, T.R., Kamran, R. and Zahra, R., 2015. Prevalence and clinical burden of NDM-1 positive infections in pediatric and neonatal patients in Pakistan. Pediatr. Infect. Dis. J., 34: 452-454. https://doi.org/10.1097/ INF.0000000000000582

Rahman, S.U., Ahmad, S. and Khan, I., 2018. Incidence of ESBL-producing-Escherichia coli in poultry farm environment and retail poultry meat. Pakistan Vet. J., 39: 116-120. https://doi.org/10.29261/ pakvetj/2018.091

Rehman, A., Jingdong, L., Chandio, A.A. and Hussain, I., 2017. Livestock production and population census in Pakistan: Determining their relationship with agricultural GDP using econometric analysis. Inf. Proc. Agric., 4: 168-177. https://doi.org/10.1016/j. inpa.2017.03.002

Reich, F., Atanassova, V. and Klein, G., 2013. Extendedspectrum $\beta$-lactamase and AmpC-producing enterobacteria in healthy broiler chickens, Germany. Emerg. Infect. Dis., 19: 1253. https://doi. org/10.3201/eid1908.120879

Runcharoen, C., Raven, K.E., Reuter, S., Kallonen, T., Paksanont, S., Thammachote, J., Anun, S., Blane, B., Parkhill, J., Peacock, S.J. and Chantratita, N., 2017. Whole genome sequencing of ESBL-producing Escherichia coli isolated from patients, farm waste and canals in Thailand. Genome Med., 9: 81. https:// doi.org/10.1186/s13073-017-0471-8

Sartor, A.L., Raza, M.W., Abbasi, S.A., Day, K.M., Perry, J.D., Paterson, D.L. and Sidjabat, H.E., 2014. Molecular epidemiology of NDM-1-producing Enterobacteriaceae and Acinetobacter baumannii isolates from Pakistan. Antimicrob. Agents Chemother, 58: 5589-5593. https://doi.org/10.1128/ AAC.02425-14

Sattar, H., Toleman, M., Nahid, F. and Zahra, R., 2016. Co-existence of blaNDM-1 and blaKPC-2 in clinical isolates of Klebsiella pneumoniae from Pakistan. $J$. Chemother, 28: 346-349. https://doi.org/10.1179/19 73947814Y.0000000223

Tekiner, I.H. and Ozpinar, H., 2016. Occurrence and characteristics of extended spectrum betalactamases-producing Enterobacteriaceae from foods of animal origin. Braz. J. Microbiol., 47: 444- 
451. https://doi.org/10.1016/j.bjm.2015.11.034

Upadhyay, S., Hussain, A., Mishra, S., Maurya, A.P., Bhattacharjee, A. and Joshi, S.R., 2015. Genetic environment of plasmid mediated CTX-M-15 extended spectrum beta-lactamases from clinical and food borne bacteria in North-Eastern India. PLoS One, 10: e0138056. https://doi.org/10.1371/ journal.pone.0138056

Van Boeckel, T. P., Brower, C., Gilbert, M., Grenfell, B. T., Levin, S. A., Robinson, T. P., Teillant, A. and Laxminarayan, R., 2015. Global trends in antimicrobial use in food animals. Proc. natl. Acad. Sci., 112: 5649-5654. https://doi.org/10.1073/ pnas. 1503141112

Weinstein, M.P., Patel, J.B., Campeau, S., Eliopoulos, G.M., Galas, M.F., Humphries, R.M., Jenkins, S.G. and II, J.S.L., 2018. Performance standars for antimiceobial susceptibility testing. Clin. Lab.
Stand. Inst., 28: 1-257.

Woodford, N., Fagan, E.J. and Ellington, M.J., 2006. Multiplex PCR for rapid detection of genes encoding CTX-M extended-spectrum (beta)-lactamases. $J$. Antimicrob. Chemother., 57: 154-155. https://doi. org/10.1093/jac/dki412

Younas, M., Rahman, S.U., Shams, S., Salman, M.M. and Khan, I., 2019. Multidrug resistant carbapenemaseproducing Escherichia coli from chicken meat reveals diversity and co-existence of carbapenemase encoding genes. Pakistan Vet. J., 39: 241-245. https://doi.org/10.29261/pakvetj/2019.047

Zarfel, G., Galler, H., Luxner, J., Petternel, C., Reinthaler, F.F., Haas, D., Kittinger, C., Grisold, A.J., Pless, P. and Feierl, G., 2014. Multiresistant bacteria isolated from chicken meat in Austria. Int. J. environ. Res. Publ. Hlth., 11: 12582-12593. https://doi. org/10.3390/ijerph111212582 